\title{
Article \\ Efficiency of Prolonged Prone Positioning for Mechanically Ventilated Patients Infected with COVID-19
}

\author{
Elizabeth M. Parker ${ }^{1}$, Edward A. Bittner ${ }^{2}$, Lorenzo Berra ${ }^{2}$ and Richard M. Pino ${ }^{2,3, *(D)}$ \\ 1 Surgical Intensive Care Unit, Massachusetts General Hospital, Boston, MA 02114, USA; \\ emparker91@gmail.com \\ 2 Department of Anesthesia, Critical Care and Pain Medicine, Massachusetts General Hospital, \\ Boston, MA 02114, USA; ebittner@mgh.harvard.edu (E.A.B.); lberra@mgh.harvard.edu (L.B.) \\ 3 Louisiana State University Health Sciences Center, Department of Anesthesiology, \\ New Orleans, LA 70112, USA \\ * Correspondence: rpino1@lsuhsc.edu
}

Citation: Parker, E.M.; Bittner, E.A.; Berra, L.; Pino, R.M. Efficiency of Prolonged Prone Positioning for Mechanically Ventilated Patients Infected with COVID-19. J. Clin. Med. 2021, 10, 2969. https://doi.org/ $10.3390 /$ jcm10132969

Academic Editor: Emmanuel Andrès

Received: 8 June 2021

Accepted: 29 June 2021

Published: 1 July 2021

Publisher's Note: MDPI stays neutral with regard to jurisdictional claims in published maps and institutional affiliations.

Copyright: (c) 2021 by the authors. Licensee MDPI, Basel, Switzerland. This article is an open access article distributed under the terms and conditions of the Creative Commons Attribution (CC BY) license (https:// creativecommons.org/licenses/by/ $4.0 /)$.

\begin{abstract}
Hypoxemia of the acute respiratory distress syndrome can be reduced by turning patients prone. Prone positioning (PP) is labor intensive, risks unplanned tracheal extubation, and can result in facial tissue injury. We retrospectively examined prolonged, repeated, and early versus later PP for 20 patients with COVID-19 respiratory failure. Blood gases and ventilator settings were collected before PP, at 1, 7, 12, 24, 32, and $39 \mathrm{~h}$ after PP, and $7 \mathrm{~h}$ after completion of PP. Analysis of variance was used for comparisons with baseline values at supine positions before turning prone. PP for $>39 \mathrm{~h}$ maintained $\mathrm{PaO}_{2} / \mathrm{FiO}_{2}(\mathrm{P} / \mathrm{F})$ ratios when turned supine; the $\mathrm{P} / \mathrm{F}$ decrease at $7 \mathrm{~h}$ was not significant from the initial values when turned supine. Patients turned prone a second time, when again turned supine at $7 \mathrm{~h}$, had significant decreased $\mathrm{P} / \mathrm{F}$. When $\mathrm{PP}$ started for an initial $\mathrm{P} / \mathrm{F} \leq 150$ versus $\mathrm{P} / \mathrm{F}>150$, the $\mathrm{P} / \mathrm{F}$ increased throughout the $\mathrm{PP}$ and upon return to supine. Our results show that a single turn prone for $>39 \mathrm{~h}$ is efficacious and saves the burden of multiple prone turns, and there is no significant advantage to initiating $\mathrm{PP}$ when $\mathrm{P} / \mathrm{F}>150$ compared to $\mathrm{P} / \mathrm{F} \leq 150$.
\end{abstract}

Keywords: acute respiratory distress syndrome; ARDS; COVID-19; respiratory failure; prone positioning; $\mathrm{PaO}_{2} / \mathrm{FIO}_{2}$ ratio; hypoxemia

\section{Introduction}

In the acute respiratory distress syndrome (ARDS) prone positioning (PP) is commonly used to increase oxygenation with the overall goal to minimize ventilator induced lung injury [1-4]. The prone position enables a better distribution of transpulmonary pressures, relieves pressure on the lung that is posterior to the heart, and improves lymphatic drainage [1]. It became clear during the initial stages of the COVID-19 pandemic that the ARDS seen in infected patients, termed CARDS, was often more challenging to manage than that seen in other non-COVID-19 conditions [5]. Intensivists found that the initial protocols for the treatment of COVID-19 were arbitrary and routinely changed as new data became available $[6,7]$. However, the use of PP remained a valuable option for the treatment of ARDS from any etiology [3].

Prone positioning is labor intensive and involves multiple caregivers to turn patients, some of whom may have high body mass indexes. It has inherently increased risks of inadvertent tracheal extubation, endotracheal tube obstruction, facial tissue injury even with optimal precautions, and tracheal stenosis [3,8-10]. Initial studies of PP identified an improvement in oxygenation but failed to identify a mortality benefit $[8,11,12]$. Subsequent reports indicated that PP decreased mortality for patients with severe ARDS, although improved oxygenation may not correlate with mortality $[2,3,13,14]$. Improvement in oxygenation after the initial PP is a significant predictor of ICU survival and the duration of PP may be an important determinant of its efficacy $[14,15]$. 
The treatment of patients with CARDS by experienced intensivists and nurses in a single ICU setting enabled us to examine the impact of duration and factors associated with prone positioning and turning patients back to the supine position, with the goal to determine the most efficient positioning regimen to increase oxygenation and decrease the potential for complications.

\section{Materials and Methods}

With the approval of the Institutional Review Board, we retrospectively examined the results of repeated prone positioning for 20 patients with respiratory failure secondary to COVID-19 infections from March to May 2020 in the Surgical Intensive Care Unit at the Massachusetts General Hospital at the height of the COVID-19 pandemic surge. A total of 25 patients with COVID-19 pneumonia were admitted during this period. Five were excluded from the study because they were stable enough not to require prone positioning. Pharmacologic treatment of COVID-19 was standardized and included hydroxychloroquine, azithromycin, and atorvastatin as per institutional guidelines in use at the time.

This ICU is staffed $24 / 7$ by critical care anesthesiologists, surgeons, and experienced nurses. Attending intensivists were directly involved with the decisions to turn prone and back to supine positions that were based on clinical judgment using P/F ratios after mechanical ventilation parameters (best positive end expiratory pressure (PEEP), driving pressures, neuromuscular blockade and sedation) were optimized. Best PEEP was determined by recruitment maneuvers or stepwise increases in PEEP [16,17] for patients with unstable hemodynamics. Prone positioning was done either by the ICU team or a hospital organized proning team. Patients in the prone position underwent intermittent head turns to prevent skin breakdown. Nasogastric tube feeding was continued in the prone position if tolerated.

Three distinct groups were selected for analyses: prolonged PP, repeated PP, and an early proning $(\mathrm{P} / \mathrm{F}$ ratio $>150)$ versus later proning $(\mathrm{P} / \mathrm{F}$ ratio $\leq 150)$. Blood gas values and mechanical ventilator settings were studied when they were obtained before PP; at $1,7,12,24,32$, and $39 \mathrm{~h}$ after PP initiation; and at $7 \mathrm{~h}$ after completion of PP. Since this is a retrospective study, the times were chosen based on the average the closest available data points in the setting of reduced availability to obtain arterial blood gases secondary to short supplies of blood gas syringes during the pandemic.

\section{Statistical Analysis}

Descriptive statistics were performed and reported as mean and standard deviation for continuous variables or as percentages for categorical data as appropriate. Comparisons of the differences between prone and supine positioning at different time points were performed using repeated measures analysis of variance. Bonferroni correction was used to account for multiple comparisons. A two-sided $p$-value of $\leq 0.05$ was used to denote statistical significance. Statistical analyses were performed using Excel ${ }^{\circledR}$ version 1908 (Microsoft ${ }^{\circledR}$ Excel $^{\circledR}$ for Office $365 \mathrm{MSO}$, Redmond, WA, USA).

\section{Results}

Table 1 summarizes the timeline from symptom onset to the first prone positioning.

\subsection{Prolonged Prone Positioning}

Twelve patients experienced 16 episodes of prolonged PP (>39 h) (Table 2) with ventilation and oxygenation data for the first $39 \mathrm{~h}$ presented in Table 3. 
Table 1. Summarizes the timeline from symptom onset to the first prone positioning.

\begin{tabular}{ccccc}
\hline \multicolumn{4}{c}{ Timeline (Days): Median (IQR) of Patients Positioned Prone (PP) } & \\
\hline Event & Prolonged PP & Repeated PP & Early PP & Late PP \\
\hline Symptom Onset to Hospital Admission & $6(4-9)$ & $5(3-7)$ & $5(4-7)$ & $6(4-8)$ \\
\hline Hospital Admission to SICU Admission & $0(0-1)$ & $0(0-1)$ & $0(0-2)$ & $1(0-2)$ \\
\hline SICU Admission to Intubation & $0(0-0)$ & $0(0-0)$ & $0(0-0)$ & $0(0-0)$ \\
\hline Intubation to First Prone Positioning & $3(1-5)$ & $4(3-4)$ & $4(3-4)$ & $4(1-5)$ \\
\hline
\end{tabular}

Table 2. Characteristics of Proned Patients.

\begin{tabular}{|c|c|c|c|c|}
\hline & Prolonged Prone & Repeated Prone & Early Prone & Late Prone \\
\hline & $\mathrm{PP}(n=12)$ & $\mathrm{PP}(n=12)$ & $\mathrm{PP}(n=10)$ & PP $(n=10)$ \\
\hline Age, years & $63.3 \pm 11.5$ & $56.6 \pm 16.3$ & $60.9 \pm 19.6$ & $57.1 \pm 22.1$ \\
\hline Men, $n(\%)$ & $9(75 \%)$ & $10(83 \%)$ & $6(60 \%)$ & $7(70 \%)$ \\
\hline \multicolumn{5}{|l|}{ Severity of ARDS } \\
\hline Mild, $n(\%)$ & $0(0 \%)$ & $0(0 \%)$ & $0(0 \%)$ & $0(0 \%)$ \\
\hline Moderate, $n(\%)$ & $4(33 \%)$ & $4(33 \%)$ & $6(60 \%)$ & $3(30 \%)$ \\
\hline Severe, $n(\%)$ & $8(67 \%)$ & $8(67 \%)$ & $4(40 \%)$ & $7(70 \%)$ \\
\hline \multicolumn{5}{|l|}{ Treatment in ICU } \\
\hline Vasopressor, $n(\%)$ & $12(100 \%)$ & $12(100 \%)$ & $10(100 \%)$ & $10(100 \%)$ \\
\hline Inhaled nitric oxide, $n(\%)$ & $7(58 \%)$ & $6(50 \%)$ & $3(30 \%)$ & $5(50 \%)$ \\
\hline Hospital Mortality, $n(\%)$ & $4(33 \%)$ & $4(33 \%)$ & $4(40 \%)$ & $3(30 \%)$ \\
\hline Duration of PP (h): median (IQR) & $57(45-66)$ & $117(97-153)$ & $84(46-112)$ & $96(57-142)$ \\
\hline ICU Length of Stay (days): median (IQR) & $20(17-33)$ & $20(17-39)$ & $20(14-25)$ & $19(16-33)$ \\
\hline Mechanical Ventilation (days): median (IQR) & $17(15-18)$ & $17(17-21)$ & $17(16-20)$ & $16(14-17)$ \\
\hline
\end{tabular}

Table 3. Ventilation and oxygenation variables throughout the first $39 \mathrm{~h}$ of the prone positioning.

\begin{tabular}{|c|c|c|c|c|c|c|c|c|}
\hline & Supine & $1 \mathrm{~h}$ & $7 \mathrm{~h}$ & $12 \mathrm{~h}$ & $24 \mathrm{~h}$ & $32 \mathrm{~h}$ & $39 \mathrm{~h}$ & $p$ Value \\
\hline $\mathrm{FiO}_{2}$ & 0.60 & 0.65 & 0.60 & 0.57 & 0.55 & 0.57 & 0.53 & 0.045 \\
\hline PEEP $\left(\mathrm{cmH}_{2} \mathrm{O}\right)$ & 13 & 13 & 13 & 13 & 13 & 13 & 13 & 0.230 \\
\hline Pplat $\left(\mathrm{cmH}_{2} \mathrm{O}\right)$ & 25.6 & 25.6 & 25.8 & 25.8 & 25.6 & 25.9 & 25.9 & 0.910 \\
\hline Cstat $\left(\mathrm{mL} / \mathrm{cmH}_{2} \mathrm{O}\right)$ & 27 & 28 & 28 & 28 & 28 & 29 & 29 & 0.834 \\
\hline $\mathrm{PaO}_{2} / \mathrm{FiO}_{2}(\mathrm{mmHg})$ & 130 & 175 & 170 & 184 & 179 & 198 & 193 & 0.000 \\
\hline
\end{tabular}

$\mathrm{FiO}_{2}$, fraction of inspired oxygen; PEEP, positive end-expiratory pressure; Pplat, plateau pressure; $\Delta \mathrm{P}$, driving pressure; Cstat, static compliance.

The average change in the $\mathrm{P} / \mathrm{F}$ ratio over the $39 \mathrm{~h}$ is illustrated in Figure 1. Compared with the mean P/F ratio prior to PP $(130 \pm 28.4)$, significant improvement was found at 1 , $7,12,24,32$, and $39 \mathrm{~h}$ after the PP start. There was no significant improvement between the mean $\mathrm{P} / \mathrm{F}$ ratio at $12 \mathrm{~h}$ and $24 \mathrm{~h}(p=0.61)$. The gain in oxygenation over the prolonged $\mathrm{PP}$ was maintained when compared to the mean P/F ratio prior to the PP completion, with no significant decreases at $7 \mathrm{~h}$ after returning prone (Figure 2). Post hoc analysis showed a significant improvement in the $\mathrm{P} / \mathrm{F}$ ratio that was evidenced immediately after $\mathrm{PP}$ initiation at $1 \mathrm{~h}$, with evidence of ongoing improvement seen between $12-24 \mathrm{~h}$. The P/F values remained constant up to $39 \mathrm{~h}$ thereafter. Following completion of prolonged PP, two patients were extubated, six patients received a tracheostomy, and four patients died. 


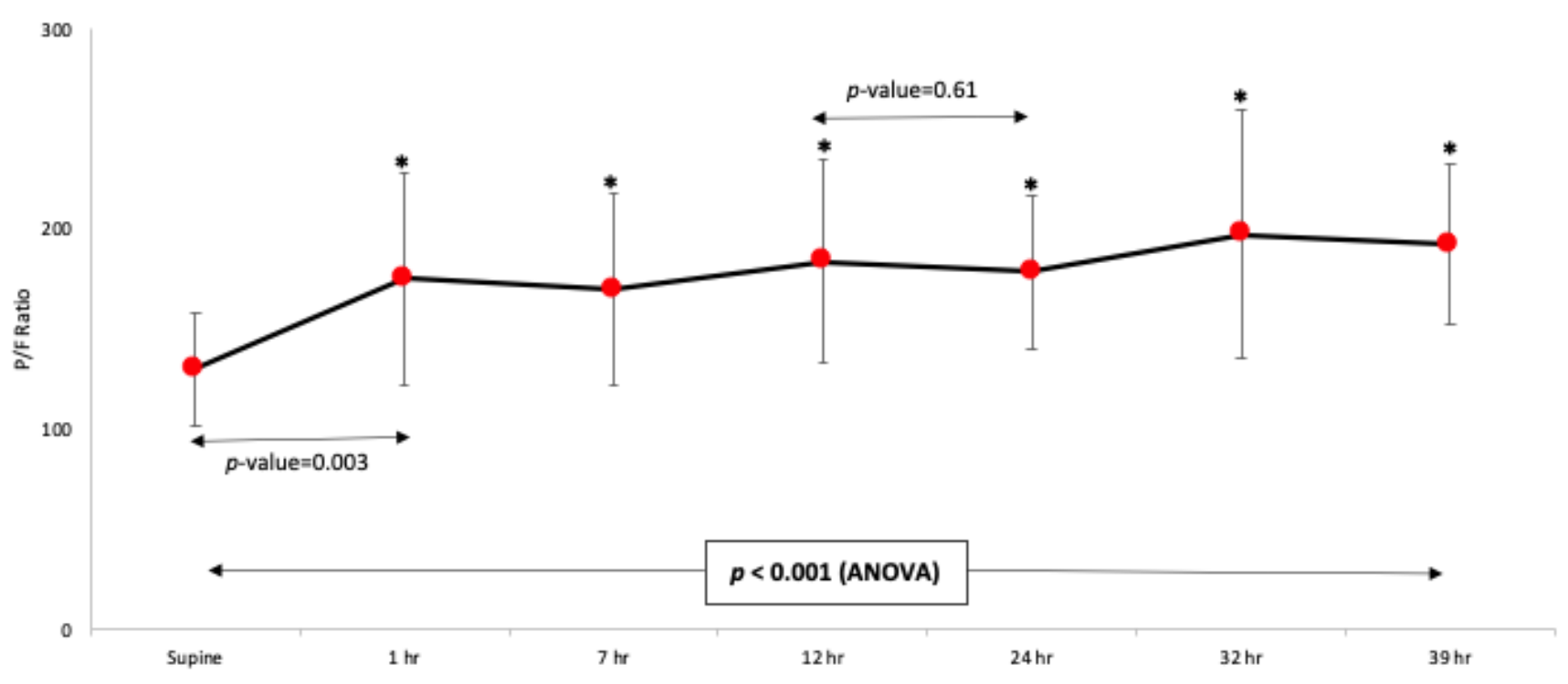

Figure 1. Time course change in $\mathrm{P} / \mathrm{F}$ ratio during the first $39 \mathrm{~h}$ of prolonged prone position. Supine represents positioning before initiating prone positioning. Compared to the mean P/F ratio prior to PP, significant improvement was found at 1,7 , 12, 24, 32, and $39 \mathrm{~h}$ after PP.

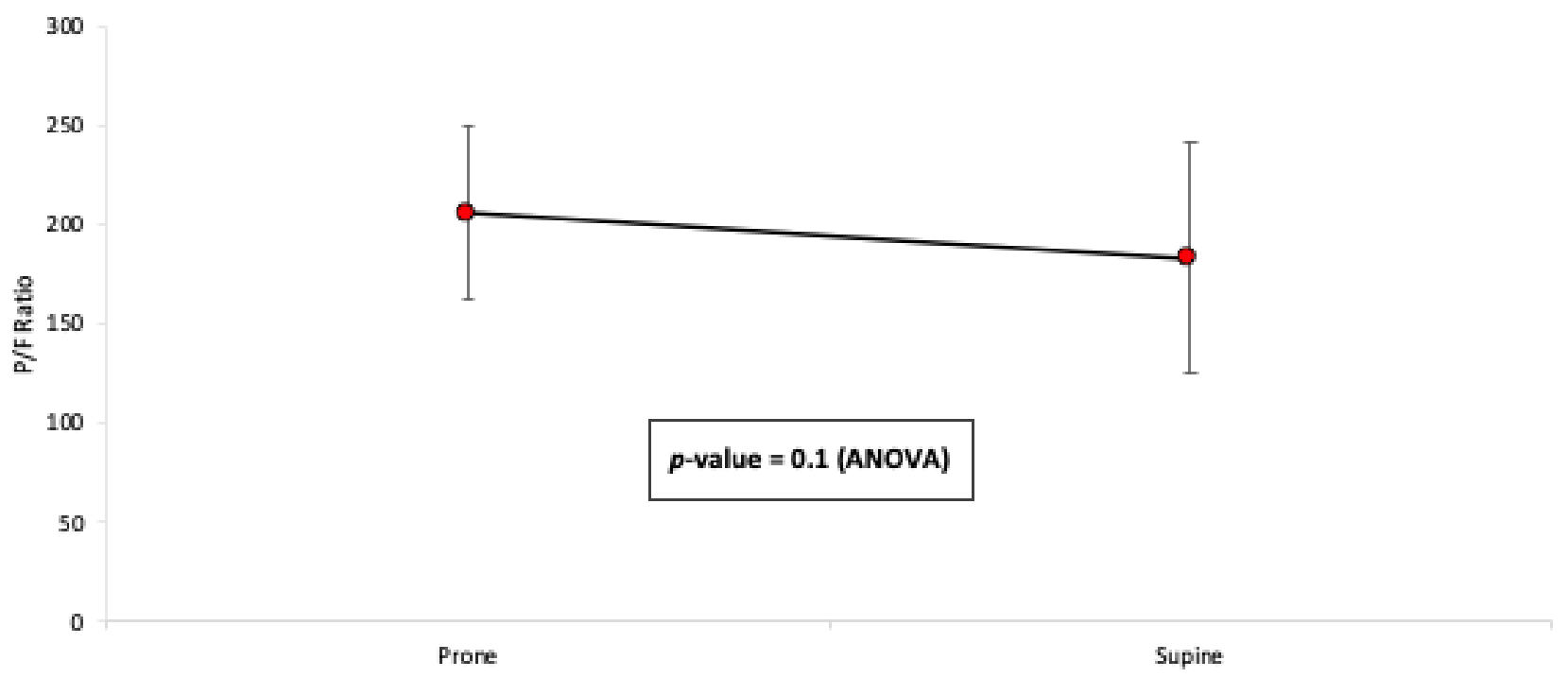

Figure 2. Mean P/F ratio before and after proning position completion. Prone represents time before turning back to the supine position. Supine represents $7 \mathrm{~h}$ after completing PP. The gain in oxygenation over the prolonged PP for $>39 \mathrm{~h}$ was maintained. There was no significant decrease at $7 \mathrm{~h}$ when PP was completed.

\subsection{Episodes of Prone Positioning Alternated with Supination}

Twelve patients experienced episodes of repeated PP (reproning). Ten patients were male, mean age $57 \pm 16.3$ years. Table 4 contains ventilation and oxygenation parameters for reproning. The changes in the P/F ratio for reproning are illustrated in Figures 3-6. Figures 3 and 4 demonstrate failures to improve after less than $39 \mathrm{~h}$ in the prone position but showed increased P/F ratios after reproning for $51 \mathrm{~h}$ (Figure 3) and $93 \mathrm{~h}$ (Figure 4). Collectively, both the first proning and reproning maintained oxygenation as there was no decrease post completion of PP (Figures 5 and 6). Following completion of PP and turning supine, three patients were extubated, five needed tracheostomies for prolonged ventilatory failure, and four patients died. 
Table 4. Ventilation and oxygenation variables for repeated prone positioning.

\begin{tabular}{ccccccccccc}
\hline & \multicolumn{3}{c}{ First Prone } & & & & \multicolumn{3}{c}{ Reprone } \\
\hline & Supine & Initial & Last & Post & $p$ Value & Supine & Initial & Last & Post & $p$ Value \\
\hline $\mathrm{FiO}_{2}$ & 0.65 & 0.69 & 0.56 & 0.57 & 0.057 & 0.59 & 0.61 & 0.57 & 0.60 & 0.872 \\
$\mathrm{PEEP}\left(\mathrm{cmH}_{2} \mathrm{O}\right)$ & 13 & 14 & 14 & 14 & 0.774 & 13 & 14 & 14 & 14 & 0.125 \\
$\mathrm{Pplat}\left(\mathrm{cmH}_{2} \mathrm{O}\right)$ & 25.7 & 25.7 & 25.3 & 24.6 & 0.041 & 24.5 & 24.5 & 25.5 & 25.5 & 0.018 \\
$\mathrm{Cstat}\left(\mathrm{mL} / \mathrm{cmH}_{2} \mathrm{O}\right)$ & 31 & 33 & 35 & 39 & 0.179 & 38 & 38 & 35 & 38 & 0.199 \\
$\mathrm{PaO}_{2} / \mathrm{FiO}_{2}(\mathrm{mmH})$ & 141 & 188 & 208 & 179 & 0.011 & 139 & 195 & 199 & 171 & 0.004 \\
\hline
\end{tabular}

Reprone, the next prone session; $\mathrm{FiO}_{2}$, fraction of inspired oxygen; PEEP, positive end-expiratory pressure; Pplat, plateau pressure; $\Delta \mathrm{P}$, driving pressure; Cstat, static compliance.

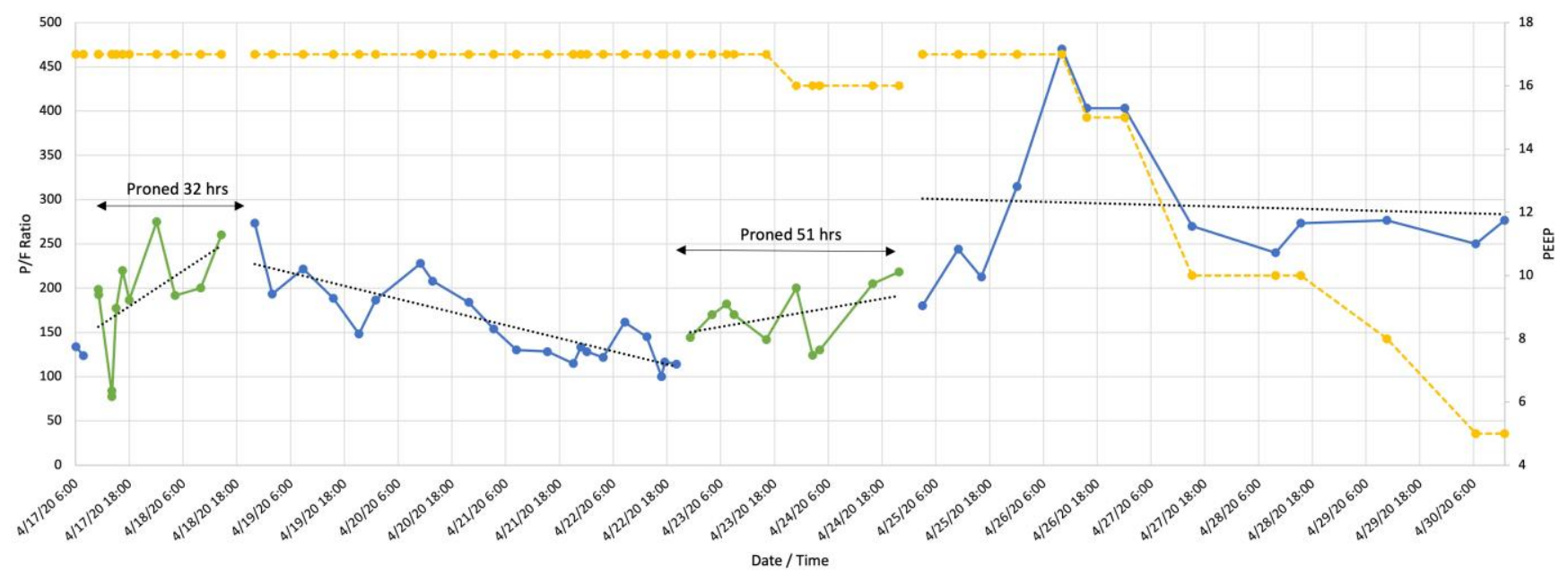

Figure 3. Patient with repeated prone positioning. Following an initial $\mathrm{P} / \mathrm{F}$ ration of 124 (blue line) the patient was turned prone (green line) for $32 \mathrm{~h}$ when P/F 260 was attained. There was a steady decline to P/F 100 at which point he was proned for $51 \mathrm{~h}$ after which time the $\mathrm{P} / \mathrm{F}$ ratio remained stable. Yellow line indicates positive end expiratory pressure (PEEP).

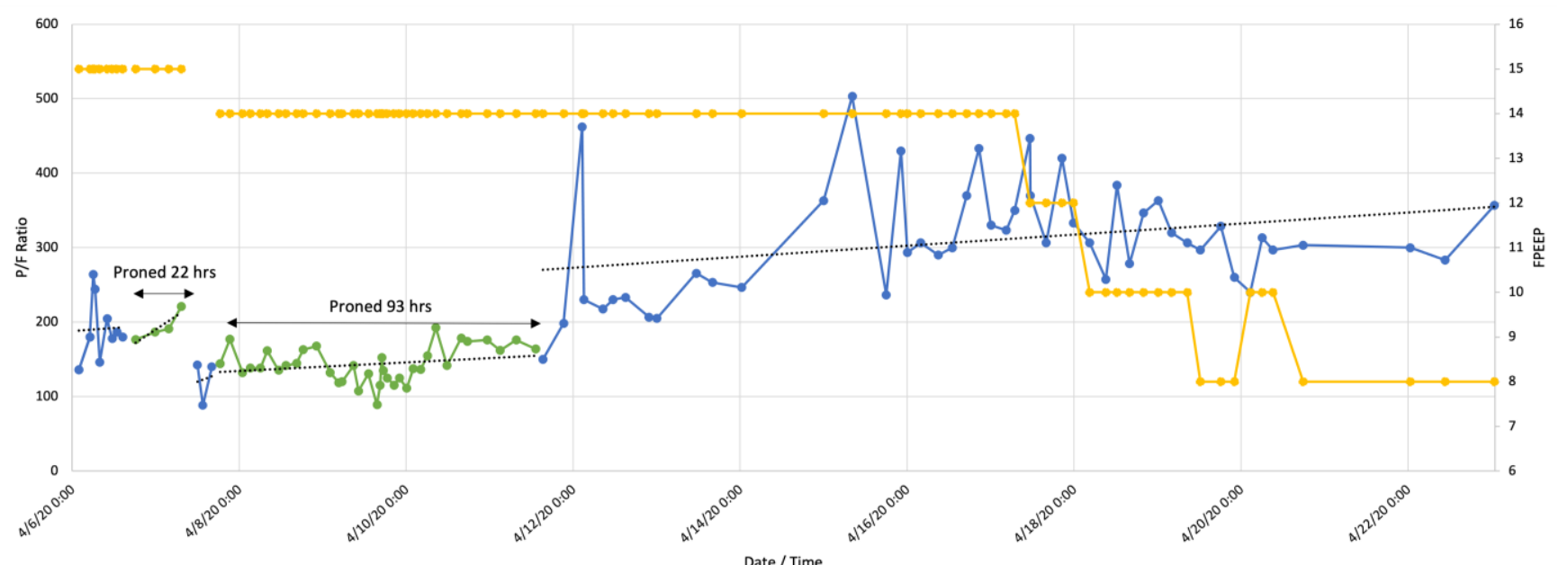

Figure 4. Patient with repeated prone positioning. Following a P/F ratio of 176 (blue line), the patient was turned prone for $22 \mathrm{~h}$ (green line), turned supine at P/F 142, and returned to the prone position for $93 \mathrm{~h}$. When turned supine again, there was a consistent trend of improving oxygenation. Yellow line indicates positive end expiratory pressure (PEEP). 


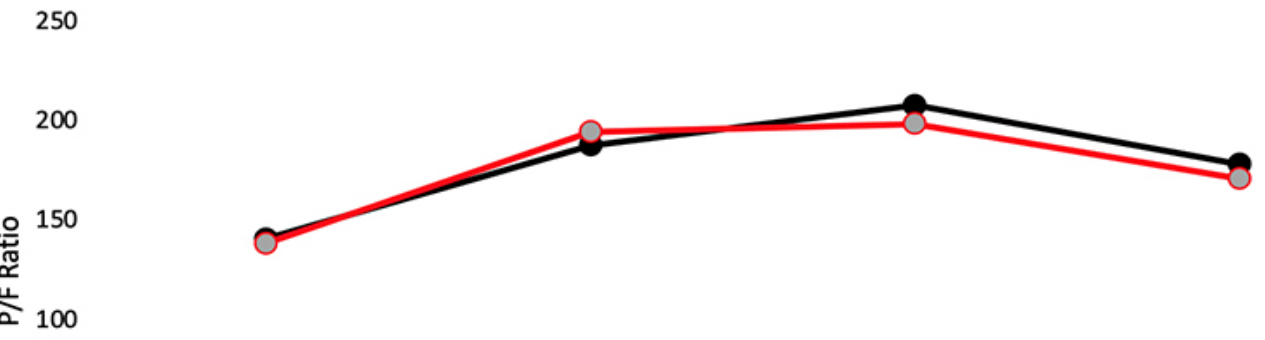

50

\begin{tabular}{rrr}
$4 \mathrm{~h}$ & $39 \mathrm{~h}$ & $7 \mathrm{~h}$ \\
\hline Supine & Initial & Last \\
& $\rightarrow$ First Prone & $\sim$ Pecond Prone
\end{tabular}

Figure 5. Time course change in P/F ratio for reproning. Supine represents immediately before PP. Post represents $7 \mathrm{~h}$ after completing PP. Reproning is not necessary to improve oxygenation compared to an initial prone.

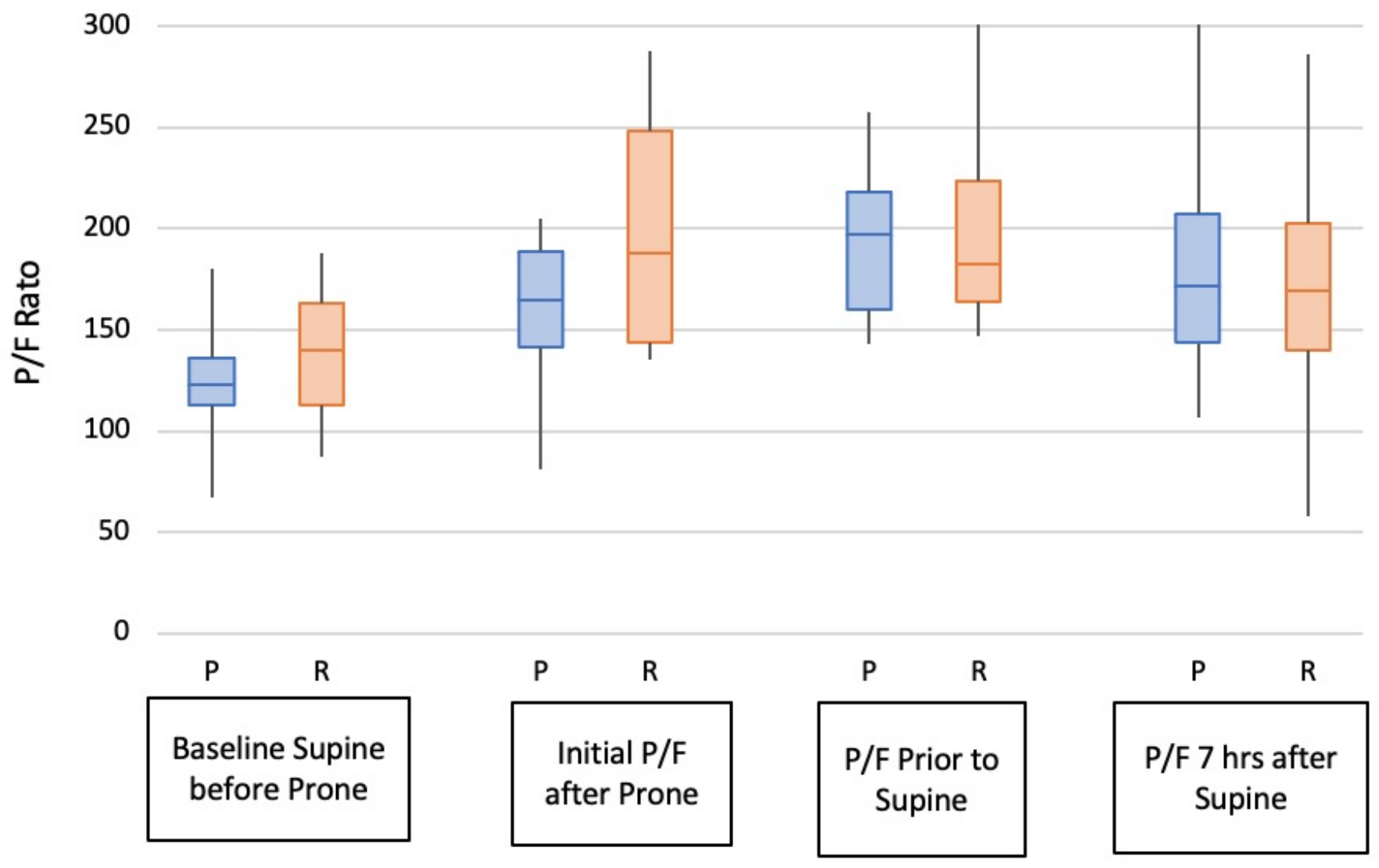

Figure 6. $\mathrm{P} / \mathrm{F}$ ratio comparison between prolonged $(\mathrm{P})$ and repeated $(\mathrm{R})$ prone positioning. Prone $\mathrm{P} / \mathrm{F}$ ratio prior to turning supine compared to baseline, $p<0.001 ; \mathrm{P} / \mathrm{F}$ for repeated prone compared to baseline, $p<0.004 ; \mathrm{P} / \mathrm{F} 7 \mathrm{~h}$ after return to supine for single prone, $p<0.019$ compared to baseline; P $/ \mathrm{F} 8 \mathrm{~h}$ after return to supine from multiple prone turns, $p<0.18$.

\subsection{Early Versus Late PP}

Ten patients underwent "early" $\mathrm{PP}$ when the $\mathrm{P} / \mathrm{F}$ ratio was $>150$ (six men, mean age $61 \pm 19.6$ years). Ten patients (seven men, age $57 \pm 22.1$ years) were placed in PP when the $\mathrm{P} / \mathrm{F}$ ratio declined to $\leq 150$. The mean change in $\mathrm{P} / \mathrm{F}$ ratio for positioning prone later versus early is illustrated in Figure 7 . There was an increase in the $\mathrm{P} / \mathrm{F}$ ratio when initiating $\mathrm{PP}$ when the $\mathrm{P} / \mathrm{F}$ ratio $\leq 150$ which was (117 vs. $175, p=0.0004)$. However, there was not a significant increase in the mean $\mathrm{P} / \mathrm{F}$ ratio when initiating $\mathrm{PP}$ when the $\mathrm{P} / \mathrm{F}$ ratio $>150$ (188 
vs. 192, $p>0.05$ ). After early PP, three patients were extubated, three patients received a tracheostomy, and four died. Two of the patients who died had single proning durations of 23 and $32 \mathrm{~h}$. Following completion of later PP, two patients were extubated, five received a tracheostomy, and three died.

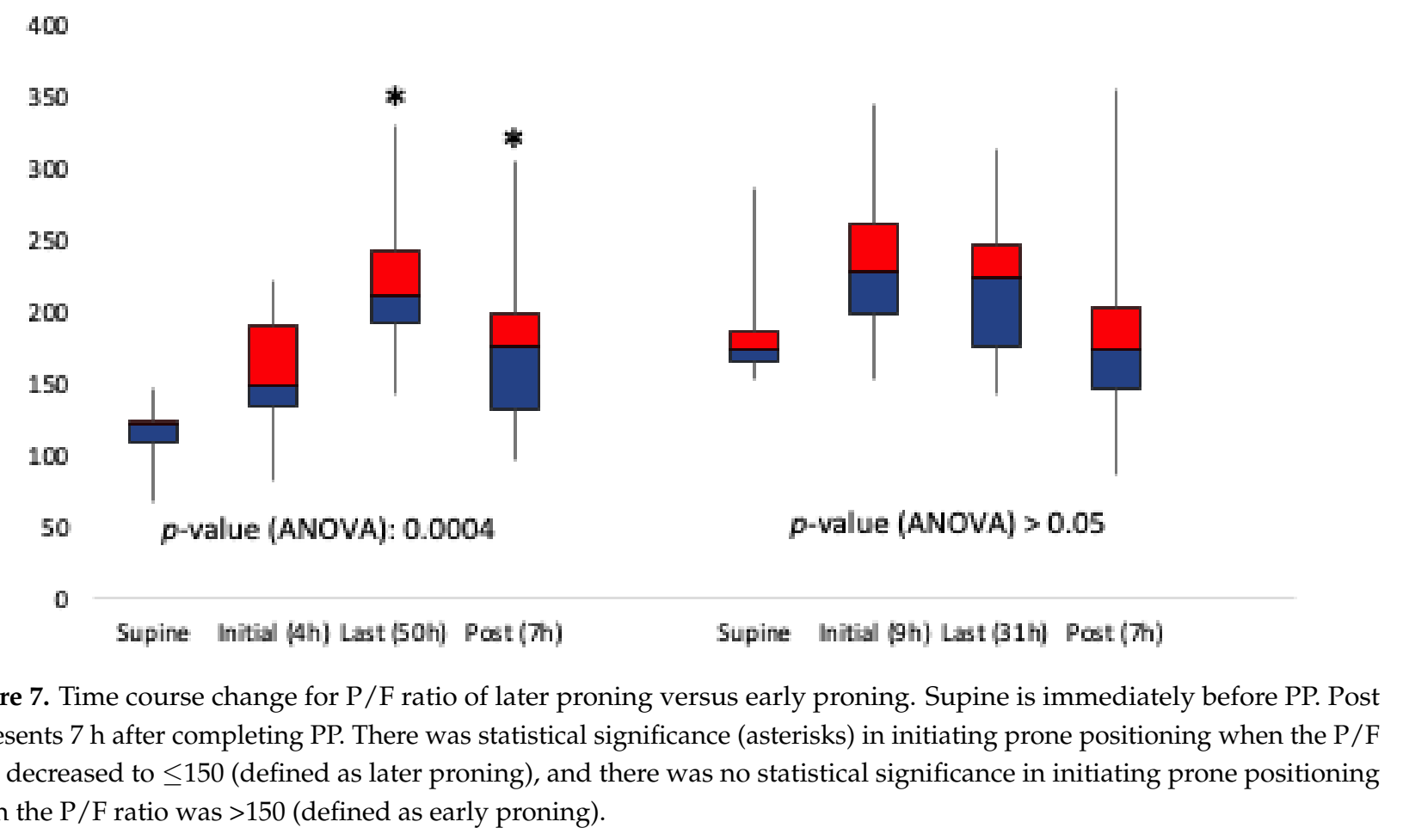

\subsection{Adverse Events}

During the course of this study period there were no inadvertent extubations or soft tissue injuries to the face related to the prone positioning.

\section{Discussion}

Our findings show that a single PP for $>39 \mathrm{~h}$ is efficacious and saves the labor-intensive burden of multiple supine to prone turns. We have also demonstrated that there is no significant advantage to starting the $\mathrm{PP}$ when $\mathrm{P} / \mathrm{F}$ was $>150$ compared to $\mathrm{P} / \mathrm{F} \leq 150$. Prior studies of PP for ARDS have focused on the benchmarks of mortality or improvements in oxygenation $[2,11,12,15,18,19]$. Many studies were published prior to the established definition of ARDS by the Berlin Criteria and the etiologies for hypoxemia were diverse and included pneumonia, sepsis, trauma, and unknown causes [8,11,12,15,18,20-23]. Exclusions included the use of high-dose vasopressors as commonly seen in many pathophysiologic states concurrent with ARDS [18]. Criteria for turning patients prone often were not well defined and were inconsistent with respect to the time course for $\mathrm{PP}$, the number of times PP was used for each patient, and the total duration of the PP (Appendix A). Ventilation strategies of earlier studies were before the advent of best PEEP [16,17]. Pre-COVID studies recommended PP for at least $12 \mathrm{~h}$ /day with the caveat that the PP is associated with tracheal tube obstruction and pressure sores $[3,13]$. For patients who were first turned prone as long as nine days after the diagnosis of ARDS, the duration of PP for patients was suggestive of an important determinant of effectiveness [15]. Progressive increases in oxygenation were seen after $18 \mathrm{~h}$ of prone positioning but the $\mathrm{P} / \mathrm{F}$ ratio for study entry was $<300$, which was higher than previously reported [24]. For patients who were in the prone position for greater than $40 \mathrm{~h}$, oxygenation improved between 8 to $16 \mathrm{~h}$ without further increases with time [25]. This is in contrast to our findings that showed continued increases in the $\mathrm{P} / \mathrm{F}$ ratio up to $39 \mathrm{~h}$ during a single prone position. For trauma patients with ARDS, 
the effects on oxygenation with prone positioning were lost during short periods of supine positioning [26]. This gives credence to our findings that prolonged prone positioning is beneficial.

The World Health Organization's guidance for COVID-19 patients with P/F ratios $<150$ is prone positioning for $12-16 \mathrm{~h}$ per day [27]. A retrospective study of 10 COVID-19 patients suggested that sustained improvement in oxygenation can be only achieved after several cycles of PP with extended times beyond $16 \mathrm{~h}$ at the cost of work overload [28]. One prospective study demonstrated that PP improved oxygenation when instituted early, but there were only eight patients requiring mechanical ventilation and the definition of early prone and duration were not defined [29]. There were no significant improvements for awake patients supported with non-invasive positive pressure ventilation who could turn themselves prone, but only half ( 23 subjects), called "responders," maintained improved oxygenation.

One limitation of our retrospective study was that the findings were for twenty patients. While several pre-COVID trials included 100 subject or more, our cohort is similar to those of other COVID and non-COVID ARDS investigations (Table 4) $[2,8,11,12,14,20$, 21,23,26-32]. The strength of our study is that PP was done for patients with a single etiology for ARDS, without exclusions, and with PP done by a dedicated small number of experienced physicians and nurses with similar practice patterns. During the COVID-19 "surge" patients were treated in intensive care units and hospital floors by caregivers who were often not trained in intensive care medicine. Given the differences in treatment, these patients would not have been valid for inclusion in our work. This is in concert with studies of focus groups that identified knowledge, resources, and team culture among the successful determinants for prone positioning [33,34]. In our retrospective study design, we cannot determine if the maintenance of the $\mathrm{P} / \mathrm{F}$ ratio was due to the positioning itself versus the progress of natural recovery that was allowed secondary to the increase in oxygenation during the prolonged prone position duration.

Our findings demonstrate that a single prone turn for $>39 \mathrm{~h}$ improves oxygenation. In addition to reducing the work effort by caregivers and exposure to the pathogen, the risk of an unplanned extubation of a hypoxemic patient is minimized. Since the prone turn for $\mathrm{P} / \mathrm{F}$ ratios $\leq 150$ shows improvement in oxygenation, the decision to change positioning from supine to prone can be delayed until there are additional clinical data to support the turn and resources available for turning support.

There is evidence that a change from supine to prone position increases endotracheal tube cuff pressures, the result of which may cause tracheal stenosis [10]. It is likely that even with judicious monitoring and adjustment of cuff pressures, frequent changes in position in an attempt to increase the $\mathrm{P} / \mathrm{F}$ ratio may result in damage to the tracheal mucosa. Our results support the limitation of supine to prone turns that should minimize the risk of tracheal injury.

Author Contributions: Conceptualization, E.M.P., R.M.P.; methodology, E.M.P., E.A.B.; formal analysis, E.M.P., E.A.B., L.B.; writing—original draft preparation, E.M.P., E.A.B., L.B., R.M.P.; project administration, R.M.P. All authors have read and agreed to the published version of the manuscript.

Funding: This research received no external funding.

Institutional Review Board Statement: The study was conducted according to the guidelines of the Declaration of Helsinki, and approved by the Institutional Review Board of Massachusetts General Hospital (protocol code \#2020P001943, 6 June 2020).

Informed Consent Statement: Patient consent was waived by the Institutional Review Board because the data were retrospective, and the patients were treated by the standard of care of the Surgical Intensive Care Unit.

Conflicts of Interest: The authors declare no conflict of interest. 


\section{Appendix A}

\begin{tabular}{|c|c|c|c|c|c|c|}
\hline \multicolumn{7}{|c|}{ Prone Positioning Trials } \\
\hline Ref. & Study & Year & \# Prone & Entrance Criteria & $\begin{array}{l}\text { Prone Positioning } \\
\text { (PP) Protocol }\end{array}$ & Study Goal \\
\hline [32] & Fridrich, et al. & 1996 & 20 & $\mathrm{P} / \mathrm{F}<200$ & $\mathrm{PP} 20 \mathrm{~h} / \mathrm{d}$ & $\begin{array}{l}\text { improvement in } \\
\text { oxygenation }\end{array}$ \\
\hline [20] & Chatte, et al. & 1997 & 32 & $\begin{array}{l}\mathrm{P} / \mathrm{F}<150 ; \mathrm{FIO}_{2}>0.5 \\
\text { after } 8 \mathrm{~h}\end{array}$ & $\begin{array}{l}\text { first PP at } 4 \text { h; } 294 \\
\text { turns }\end{array}$ & $\begin{array}{l}\text { improvement in } \\
\text { oxygenation }\end{array}$ \\
\hline [11] & Gattinoni, et al. & 2001 & 152 & $\begin{array}{l}\mathrm{P} / \mathrm{F}<200, \mathrm{PEEP}>5^{\mathrm{a}} \\
\mathrm{P} / \mathrm{F}<300 \mathrm{PEEP}>10\end{array}$ & $>6 \mathrm{~h} / \mathrm{d}$ for 10 days & 10 day mortality \\
\hline$[24]$ & McAuley, et al. & 2002 & 11 & $\mathrm{P} / \mathrm{F}<300 \mathrm{PEEP}>10$ & PP $18 \mathrm{~h}$ & $\begin{array}{l}\text { improvement in } \\
\text { oxygenation }\end{array}$ \\
\hline [21] & Watanabe, et al. & 2002 & 16 & $\begin{array}{l}\mathrm{P} / \mathrm{F}<200, \mathrm{PEEP}>5 \\
\mathrm{POD} 5\end{array}$ & $6 \mathrm{~h}$ for 4 days & efficacy \\
\hline [8] & Guerin, et al. & 2004 & 413 & $\mathrm{P} / \mathrm{F}<300$ & median 4 days; $8 \mathrm{~h} / \mathrm{d}$ & 28 day mortality \\
\hline [15] & Mancebo, et al. & 2006 & 76 & $\begin{array}{l}\text { 0-9 d after ARDS } \\
\text { diagnosis }\end{array}$ & $17 \mathrm{~h} / \mathrm{d} ; 718$ turns & $\begin{array}{l}\text { decrease in mortality if } \\
\text { PP early }\end{array}$ \\
\hline [18] & $\begin{array}{l}\text { Fernandez, } \\
\text { et al. }\end{array}$ & 2008 & 40 & $\begin{array}{l}\text { within } 48 \mathrm{~h} \text { of ARDS } \\
\text { diagnosis }\end{array}$ & $\begin{array}{l}>20 \mathrm{~h} / \mathrm{d} \text {; supine if } \\
\text { stable }>12 \mathrm{~h}\end{array}$ & $\begin{array}{l}15 \% \text { mortality } \\
\text { reduction }\end{array}$ \\
\hline [12] & Taccone, et al. & 2009 & 168 & $\begin{array}{l}\mathrm{P} / \mathrm{F}<200, \text { PEEP } 5-10 \\
\text { POD } 5\end{array}$ & $18-20 \mathrm{~h} / \mathrm{d}$ & $28 \mathrm{~d}$ mortality \\
\hline [2] & Guerin, et al. & 2013 & 237 & $\mathrm{PaO}_{2}<150^{\mathrm{b}} \mathrm{FIO}_{2}>0.6$ & $\mathrm{PP}>16 \mathrm{~h}$ & $\begin{array}{l}\mathrm{P} / \mathrm{F} \text { at } 3 \& 5 \text { days; } 28 \mathrm{~d} \\
\text { mortality }\end{array}$ \\
\hline [25] & $\begin{array}{l}\text { Miyamoto, } \\
\text { et al. }\end{array}$ & 2014 & 15 & $\begin{array}{l}\text { ARDS: mild, moderate, } \\
\text { severe }\end{array}$ & $\mathrm{PP}>40 \mathrm{~h}$ & $\begin{array}{l}\text { improvement in } \\
\text { oxygenation }\end{array}$ \\
\hline [23] & Guerin, et al. & 2018 & 101 & $\begin{array}{l}\mathrm{P} / \mathrm{F}<150 ; \mathrm{PEEP}>5 \\
\mathrm{FIO}_{2}>0.6, \mathrm{PEEP}>5\end{array}$ & 16-23 h; irst PP & $\begin{array}{l}\text { prevalence in PP, } 20 \\
\text { countries }\end{array}$ \\
\hline [26] & Carsetti, et al. & 2020 & 10 & COVID; no definition & $16 \mathrm{~h}$ standard; $36 \mathrm{~h}$ & feasibility of $\mathrm{PP}>16 \mathrm{~h}$ \\
\hline [28] & Coppo, et al. & 2020 & 47 & $\begin{array}{l}\text { COVID; NIPPV c; } \\
\text { initial } \text { PO }_{2} \text { 114-119 }\end{array}$ & $3-8 \mathrm{~h}$ & $\begin{array}{l}\text { responders v non } \\
\text { responders }\end{array}$ \\
\hline [27] & Zang, et al. & 2020 & 23 & $\begin{array}{l}\text { COVID; no definition; } \\
\mathrm{SpO}_{2} 86-93 \%\end{array}$ & $6-30 \mathrm{~h}$ & $\begin{array}{l}\text { changes in ROX } \\
\text { index }\end{array}$ \\
\hline [30] & $\begin{array}{l}\text { Mettermaier, } \\
\text { et al. }\end{array}$ & 2020 & 9 & COVID; $\mathrm{PaO}_{2}<150$ & $\begin{array}{l}\text { PP mean } 15.4 \mathrm{~h} ; \\
2.8-9.6 / \mathrm{d}\end{array}$ & $\begin{array}{l}\text { improvement in } \\
\text { oxygenation }\end{array}$ \\
\hline [31] & Taboada, et al. & 2021 & 7 & COVID; $\mathrm{P} / \mathrm{F}<200$ & PP 10 h; 16 sessions & $\begin{array}{l}\text { improvement in } \\
\text { oxygenation }\end{array}$ \\
\hline [14] & Lee, et al. & 2020 & 116 & $\begin{array}{l}\mathrm{P} / \mathrm{F}<150 ; \mathrm{FIO}_{2}>0.6 \\
\mathrm{PEEP}>5\end{array}$ & $\mathrm{PP}>24 \mathrm{~h}$ & $28 \mathrm{~d}$ mortality \\
\hline
\end{tabular}

${ }^{\mathrm{a}} \mathrm{cm} \mathrm{H} \mathrm{O}_{2}{ }^{\mathrm{b}} \mathrm{mm} \mathrm{Hg} ;{ }^{\mathrm{c}}$ non-invasive positive pressure ventilation; ${ }^{\mathrm{d}}$ ratio of $\mathrm{SpO}_{2} / \mathrm{FIO}_{2}$ to respiratory rate.

\section{References}

1. Gattinoni, L.; Marini, J.J.; Pesenti, A.; Quintel, M.; Mancebo, J.; Brochard, L. The "baby lung" became an adult. Intensive Care Med. 2016, 42, 663-673. [CrossRef]

2. Guérin, C.; Reignier, J.; Richard, J.-C.; Beuret, P.; Gacouin, A.; Boulain, T.; Mercier, E.; Badet, M.; Mercat, A.; Baudin, O.; et al. Prone positioning in severe acute respiratory distress syndrome. N. Engl. J. Med. 2013, 368, 2159-2168. [CrossRef] [PubMed]

3. Fan, E.; Del Sorbo, L.; Goligher, E.C.; Hodgson, C.L.; Munshi, L.; Walkey, A.J.; Adhikari, N.K.; Amato, M.B.; Branson, R.; Brower, R.G.; et al. An official American Thoracic Society/European Society of Intensive Care Medicine/Society of Critical Care Medicine clinical practice guideline: Mechanical ventilation in adult patients with acute respiratory distress syndrome. Am. J. Respir. Crit. Care Med. 2017, 195, 1253-1263. [CrossRef] 
4. Brochard, L.; Slutsky, A.; Pesenti, A. Mechanical ventilation to minimize progression of lung injury in acute respiratory failure. Am. J. Respir. Crit. Care Med. 2017, 195, 438-442. [CrossRef]

5. Marini, J.J.; Gattinoni, L. Management of COVID-19 respiratory distress. JAMA 2020, 323, 2329-2330. [CrossRef] [PubMed]

6. Zhang, C.; Huang, S.; Zheng, F.; Dai, Y. Controversial treatments: An updated understanding of the coronavirus disease 2019. J. Med. Virol. 2020, 92, 1441-1448. [CrossRef]

7. Sharma, A.; Tiwari, S.; Deb, M.K.; Marty, J.L. Severe acute respiratory syndrome coronavirus-2 (SARS-CoV-2): A global pandemic and treatment strategies. Int. J. Antimicrob. Agents 2020, 56, 106054. [CrossRef]

8. Guerin, C.; Gaillard, S.; Lemasson, S.; Ayzac, L.; Girard, R.; Beuret, B.; Palmier, B.; Viet Le, Q.; Sirodot, M.; Rosselli, S.; et al. Effects of systemic prone positioning in hypoxemic acute respiratory failure. A randomized controlled trial. JAMA 2004, 292, $2379-2387$. [CrossRef]

9. Jiang, S.T.; Fang, C.H.; Chen, J.-T.; Smith, R.V. The face of COVID-19: Facial pressure wounds related to prone positioning in patients undergoing ventilation in the intensive care unit. Otolaryngol. Neck Surg. 2020, 164, 300-301. [CrossRef] [PubMed]

10. Piazza, C.; Filauro, M.; Dikkers, F.G.; Nouraei, S.A.R.; Sandu, K.; Sittel, C.; Amin, M.R.; Campos, G.; Eckel, H.E.; Peretti, G. Long-term intubation and high rate of tracheostomy in COVID-19 patients might determine an unprecedented increase of airway stenoses: A call to action from the European Laryngological Society. Eur. Arch. Otorhinolaryngol. 2020, 278, 1-7. [CrossRef]

11. Gattinoni, L.; Tognoni, G.; Pesenti, A.; Taccone, P.; Masheroni, D.; Labarta, V.; Malacrida, R.; Di Giulio, P.; Fumagalli, R.; Pelosi, P.; et al. Effect of Prone Positioning on the Survival of Patients with Acute Respiratory Failure. N. Engl. J. Med. 2001, 345, 568-573. [CrossRef]

12. Taccone, P.; Pesenti, A.; Latini, R.; Polli, F.; Vagginelli, F.; Mietto, C.; Caspani, L.; Raimondi, F.; Bordone, G.; Iapichino, G.; et al. Prone positioning in patients with moderate and severe acute respiratory distress syndrome: A randomized controlled trial. JAMA 2009, 302, 1977-1984. [CrossRef] [PubMed]

13. Munshi, L.; Del Sorbo, L.; Adhikari, N.K.J.; Hodgson, C.L.; Wunsch, H.; Meade, M.O.; Uleryk, E.; Mancebo, J.; Pesenti, A.; Ranieri, V.M.; et al. Prone position for acute respiratory distress syndrome. A systemic review and meta-analysis. Ann. Am. Thorac. Soc. 2017, 14, S280-S288. [CrossRef] [PubMed]

14. Lee, H.Y.; Cho, J.; Kwak, N.; Choi, S.M.; Lee, J.; Park, Y.S.; Lee, C.-H.; Yoo, C.-G.; Kim, Y.W.; Lee, S.-M. Improved oxygenation after prone positioning may be a predictor of survival in patients with acute respiratory distress syndrome. Crit. Care Med. 2020, 48, 1729-1736. [CrossRef]

15. Mancebo, J.; Fernandez, R.; Blanch, L.; Rialp, G.; Gordo, F.; Ferrer, M.; Rodríguez, F.; Garro, P.; Ricart, P.; Vallverdú, I.; et al. A multicenter trial of prolonged prone ventilation in severe acute respiratory distress syndrome. Am. J. Respir. Crit. Care Med. 2006, 173, 1233-1239. [CrossRef] [PubMed]

16. Umbrello, M.; Formenti, P.; Bolgiaghi, L.; Chiumello, D. Current concepts of ARDS: A narrative review. Int. J. Mol. Sci. 2017, 18, 64. [CrossRef]

17. Cressoni, M.; Chiumello, D.; Algieri, I.; Brioni, M.; Chiurazzi, C.; Colombo, A.; Colombo, A.; Crimella, F.; Guanziroli, M.; Tomic, I.; et al. Opening pressures and atelectrauma in acute respiratory distress syndrome. Intensive Care Med. 2017, 43, 603-611. [CrossRef]

18. Fernandez, R.; Trenchs, X.; Klamburg, J.; Castedo, J.; Serrano, J.M.; Besso, G.; Tirapu, J.P.; Santos, A.; Mas, A.; Parraga, M.; et al. Prone positioning in acute respiratory distress syndrome: A multicenter randomized clinical trial. Intensive Care Med. 2008, 34, 1487-1491. [CrossRef] [PubMed]

19. Bellani, G.; Laffey, J.G.; Pham, T.; Fan, E.; Brochard, L.; Esteban, A.; Gattinoni, L.; Van Haren, F.; Larsson, A.; McAuley, D.F.; et al. Epidemiology, patterns of care, and mortality for patients with acute respiratory distress syndrome in intensive care units in 50 countries. JAMA 2016, 315, 788-800. [CrossRef]

20. Chatte, G.; Sab, J.M.; Dubois, J.M.; Sirodot, M.; Gaussorgues, P.; Robert, D. Prone position in mechanically ventilated patients with severe acute respiratory failure. Am. J. Respir. Crit. Care Med. 1997, 155, 473-478. [CrossRef]

21. Watanabe, I.; Fujihara, H.; Sato, K.; Honda, T.; Ohashi, S.; Endoh, H.; Yamakura, T.; Taga, K.; Shimoji, K. Beneficial effect of a prone position for patients with hypoxemia after transthoracic esophagectomy. Crit. Care Med. 2002, 30, 1799-1802. [CrossRef] [PubMed]

22. ARDS Definition Task Force; Ranieri, V.M.; Rubenfeld, G.D.; Thompson, B.T.; Ferguson, N.D.; Caldwell, E.; Fan, E.; Camporota, L.; Slutsky, A.S. Acute respiratory distress syndrome: The Berlin Definition. JAMA 2012, 307, 2526-2533. [CrossRef]

23. Guérin, C.; Beuret, P.; Constantin, J.M.; Bellani, G.; Garcia-Olivares, P.; Roca, O.; Meertens, J.H.; Maia, P.A.; Becher, T.; Peterson, J.; et al. A prospective international observational prevalence study on prone positioning of ARDS patients: The APRONET (ARDS Prone Position Network) study. Intensive Care Med. 2018, 44, 22-37. [CrossRef]

24. McAuley, D.F.; Giles, S.; Fichter, H.; Perkins, G.; Gao, F. What is the optimal duration of ventilation in the prone position in acute lung injury and acute respiratory distress syndrome? Intensive Care Med. 2002, 28, 414-418. [CrossRef] [PubMed]

25. Miyamoto, K.; Kawazoe, Y.; Yasuda, M.; Shibata, N.; Nakashima, T.; Kida, M.; Kato, S. Oxygenation improves during the first 8 $\mathrm{h}$ of extended duration prone positioning in patients with respiratory failure: A retrospective study. Intensive Care $2014,2,52$. [CrossRef]

26. Fridrich, P.; Krafft, P.; Hochleuthner, H.; Mauritz, W. The effects of long-term prone positioning in patients with trauma-induced adult respiratory distress syndrome. Anesth. Analg. 1996, 83, 1206-1211. [CrossRef] 
27. World Health Organization. WHO Clinical Management of COVID-19: Interim Guidance, 27 May 2020. WHO WHO/2019nCoV/clinical/2020.5. Available online: https://apps.who.int/iris/handle/10665/332196 (accessed on 1 July 2021).

28. Carsetti, A.; Paciarini, A.D.; Marini, B.; Pantanetti, S.; Adrario, E.; Donati, A. Prolonged prone position ventilation for SARS-CoV-2 patients is feasible and effective. Crit. Care 2020, 24, 225. [CrossRef]

29. Zang, X.; Wang, Q.; Zhou, H.; Liu, S.; Xue, X.; on behalf of COVID-19 Early Prone Position Study Group. Efficacy of early prone position for COVID-19 patients with severe hypoxia: A single-center prospective cohort study. Intensive Care Med. 2020, 46, 1927-1929. [CrossRef]

30. Coppo, A.; Bellani, G.; Winterton, D.; Di Pierro, M.; Soria, A.; Faverio, P.; Cairo, M.; Mori, S.; Messinesi, G.; Contro, E.; et al. Feasibility and physiological effects of prone positioning in non-intubated patients with acute respiratory failure due to COVID-19 (PRON-COVID): A prospective cohort study. Lancet 2020, 8, 765-774. [CrossRef]

31. Mittermaier, M.; Pickerodt, P.; Kurth, F.; Bosquillon de Jarcy, L.; Uhrig, A.; Garcia, C.; Machleidt, F.; Pergantis, P.; Weber, S.; Li, Y.; et al. Evaluation of PEEP and prone positioning in early COVID-19 ARDS. EClinicalMedicine 2020, 28, 100579. [CrossRef]

32. Taboada, M.; González, M.; Álvarez, A.; González, I.; García, J.; Eiras, M.; Vieito, M.D.; Naveira, A.; Otero, P.; Campaña, O.; et al. Effectiveness of prone positioning in nonintubated intensive care unit patients with moderate to severe acude respiratory distress syndrome by Coronavirus disease 2019. Anesth. Analg. 2021, 132, 25-30. [CrossRef] [PubMed]

33. Doussot, A.; Ciceron, F.; Cerutti, E.; Salomon du Mont, L.; Thines, L.; Capellier, G.; Pretalli, J.-B.; Evrard, P.; Vettoretti, L.; Garbuio, P.; et al. Prone positioning for severe acute respiratory distress syndrome in COVID-19 patients by a dedicated team. A safe and pragmatic reallocation of medical and surgical work force in response to the outbreak. Ann. Surg. 2020, 272, e311-e315. [CrossRef] [PubMed]

34. Klaiman, T.; Silvestri, J.A.; Srinivasan, T.; Szymanski, S.; Tran, T.; Oredeko, F.; Sjoding, M.W.; Fuchs, B.D.; Maillie, S.; Jablonski, J.; et al. Improving prone positioning for severe ARDS during the COVID-19 pandemic: An implementation mapping approach. Ann. Am. Thorac. Soc. 2021, 18, 300-307. [CrossRef] [PubMed] 